\title{
POVEZANOST ZRELOSTI UČENIKA NA UPISU U PRVI RAZRED I NJIHOVA USPJEHA NA KRAJU ŠKOLSKE GODINE
}

\author{
Lana Jelinek \\ OŠ Frana Krste Frankopana, Osijek, Republika Hrvatska
}

\begin{abstract}
Sažetak
Rad se bavi rezultatima ispitivanja djece školskih obveznika, a koje provodi školski pedagog, i njihovih uspjeha na kraju prvog razreda. Na teroijskoj razini govori se o pojmu zrelosti i spremnosti djeteta za polazak u prvi razred. Cilj je bio utvrditi jesu li rezultati Upitnika za procjenu zrelosti za prvi razred povezani sa školskim uspjehom, posebice matematičko predznanje $s$ uspjehom u Matematici i govorno-jezični razvoj s uspjehom u Hrvatskom jeziku te ukupni bodovi upitnika s općim školskim uspjehom na kraju prvog razreda. Istraživanje je provedeno na uzorku od 60 učenika koji su 2016./2017. školske godine završili prvi razred, a s kojima je 2015./2016. školske godine obavljena procjena zrelosti za upis u prvi razred. Podaci su se prikupili analizom pedagoške dokumentacije odnosno uvidom u razrednu knjigu (imenik) učenika prvog razreda te uvidom u Upitnike za procjenu zrelosti za upis u prvi razred. Dobiveni rezultati ukazuju na povezanost spremnosti djeteta kod provođenja ispitivanja školske pedagoginje i njihova uspjeha na kraju školske godine. Rezultati Upitnika važni su kako bi se učitelji i stručna služba upoznali s razvojnim razlikama među učenicima, sposobnostima i predznanjem djece te kako bi se učenici mogli ravnomjerno podijeliti u razredne odjele.
\end{abstract}

Ključne riječi: govorno-jezični razvoj,matematičko predznanje, prvi razred, školski uspjeh, zrelost za školu

\section{UVOD}

Na spremnost djeteta za polazak u školu utječu mnogobrojni faktori, a najčešće se govori o fizičkoj, intelektualnoj te emocionalnoj i socijalnoj psihofizičkoj zrelosti. Brojni hrvatski autori bave se definiranjem zrelosti i spremnosti za školu (Furlan, 1984; Hitrec, 1991; Režek, 1998; Somolanji Tokić, 2016), no manji broj hrvatskih autora istražuje povezanost spremnosti za školu i budućeg uspjeha (Čudina-Obradović, 1999b). Spomenutom tematikom uglavnom se bave strani autori (Duncan, 2006; Le i sur., 2006; Marjanovič Umek i sur., 2006; Lemelin i sur., 2007; Fitzpatrick, 2011; Zhang, 2013).

Zrelost za polazak djece u školu određuje se prema dvama bitnim kriterijima. Prvi je kronološka dob, odnosno sva djeca koja navršavaju šest godina u razdoblju do 1. travnja tekuće godine školski su obveznici. Drugi je kriterij psihofizička zrelost svakog pojedinog djeteta koja, osim razvijenih intelektualnih sposobnosti (pamćenja, koncentracije i rezoniranja), traži i posjedovanje određenih vještina i znanja te određen stupanj socioemocionalne zrelosti (Zakon o odgoju i obrazovanju u osnovnoj i srednjoj školi, 2008, 19).

$\mathrm{Na}$ izbor problema istraživanja utjecali su osobni afiniteti, odnosno detaljnije proučavanje odabrane teme koja će biti korisna za buduće susrete s utvrđivanjem psihofizičkog stanja djeteta. Također, budući da su u bavljenju sličnom temom hrvatski autori u manjini, vjerujem da će rezultati istraživanja poslužiti potrebama same prakse odgoja i obrazovanja, primjerice, 
$\mathrm{u}$ individualiziranijem pristupu djeci koja su postigla slabije rezultate na Upitniku. Polazak djeteta u školu jedan je od najvažnijih razdoblja djetetova života, a jedan od načina na koji bi se djetetu moglo pomoći je usuglašavanje očekivanja svih subjekata uključenih u život djeteta.

\section{Zrelost ili spremnost djeteta za školu}

U pedagoškoj literaturi može se naći nekoliko pojmova kojima se želi označiti stanje djeteta prije polaska u školu. Furlan (1984) predlaže termine pripremljenost ili gotovost, Oštarčević u svom Priručniku (2008) rabi termin zrelost dok Režek (1998) i Hitrec (1991) rabe termine pripremljenost i zrelost kao sinonime, iako Hitrec naglašava da je pripremljenost adekvatnija riječ. U stranoj literaturi češće se koristi pojam spremnost za školu (Duncan, 2006; Le i sur., 2006; Marjanovič Umek i sur., 2006; Lemelin i sur., 2007; Fitzpatrick, 2011; Zhang, 2013), a i psiholozi se pri utvrđivanju psihofizičkog stanja djeteta koriste Testom spremnosti za školu. Pedagozi se služe upitnikom koji je kreirala Oštarčević (2008) uz pomoć stručnih suradnika iz cijele Hrvatske, a puni je naziv upitnika Upitnik za procjenu zrelosti za upis u prvi razred. Može se primijetiti kako se koriste mnogi termini kao sinonimi te će se i u ovom radu upotrebljavati pojmovi zrelost i spremnost kao sinonimi, no prvo će se objasniti u čemu je razlika u navedenim terminima.

Furlan (1984) navodi kako termin zrelosti ima biološki prizvuk pa se upotrebom tog termina dobiva dojam da je osposobljenost za određene aktivnosti rezultat samo biološkog rasta i razvoja, a za uspješno rješavanje životnih zadataka potrebno je i prethodno učenje, odnosno iskustvo te autor radije odabire nazive pripremljenost ili gotovost. Hitrec (1991) se slaže da je zrelost rezultat procesa sazrijevanja koji je biološki uvjetovan dok pripremljenost, osim sazrijevanja, uključuje i sva iskustva i znanja koje je dijete steklo do škole kao i motivaciju za učenje. S druge strane, Oštarčević $(2008$, str. 5) se ne zadržava na objašnjavanju razlike među pojmovima, već spominje samo zrelost te navodi kako zrelost za školu predstavlja „optimalan stupanj razvijenosti različitih fizičkih i psihičkih funkcija djeteta koje će mu omogućiti optimalno savladavanje propisanoga nastavnog plana i programa."

Zrelost za školu podrazumijeva karakteristike koje ima većina djece na početku osnovnoga školovanja. Upravo te karakteristike i čine sadržaj onoga što zovemo zrelost za školu, a od njih polazi i školski program. Zrelost za školu tako ima više aspekata pa je uobičajeno govoriti o fizičkoj, intelektualnoj i emocionalno-socijalnoj zrelosti (Hitrec, 1991). Prema suvremenom razumijevanju kognitivni razvoj uvelike ovisi o prirodi i kvaliteti interakcija koje predškolsko dijete ostvaruje sa svojom okolinom.

\section{Podjela psihofizičke zrelosti djeteta}

Psihofizička zrelost djeteta dijeli se na tri osnovne vrste zrelosti - fizičku, intelektualnu i socioemocionalnu zrelost (Furlan, 1984; Hitrec, 1991).

Fizička razvijenost djeteta procjenjuje se određenim pokazateljima od kojih su visina $\mathrm{i}$ težina najuočljiviji, a tu vrstu razvijenosti procjenjuje školski liječnik. Režek (1998) fizičku zrelost uspoređuje sa spremnošću za školu te navodi da najveći trud neće dati zadovoljavajuće rezultate ako se s učenjem počne prije nego je postignut određen stupanj zrelosti živčanoga sustava i organa u cjelini, a posljedica slabog uspjeha gubitak je motivacije za daljnje učenje. Fizički razvoj podrazumijeva i razvoj motorike. Razvoj motorike podrazumijeva djetetovu sve veću sposobnost svrhovitog i skladnog korištenja vlastitog tijela za kretanje i baratanje predmetima (Starc i sur., 2004).

Intelektualna zrelost podrazumijeva adekvatnu govornu razvijenost, razvijenost opažanja, mišljenja i pamćenja koji su blisko povezani s opsegom i stabilnošću pažnje. Osim toga, intelektualno-spoznajna zrelost uključuje i razvijeno realno mišljenje, sposobnost zaključivanja, rješavanja problema, razlikovanje, analogiju, preoblikovanje, prostornu i vremensku orijenta- 
ciju, razumijevanje kvantitativnih odnosa, mogućnost koncentracije i pažnje od 20 minuta i duže, uspješno uključivanje u školski rad i učenje (Markulin i Simić, 2003).

Emocionalna zrelost za školu podrazumijeva djetetovu stečenu emocionalnu stabilnost i kontrolu. To znači da dijete ima određenu razinu tolerancije na frustracije koja će mu omogućiti da ustraje u školskom učenju i onda kad mu baš nije zanimljivo ili ugodno. S druge strane, emocionalno nezrelo dijete lako gubi motivaciju za učenje, slabo kontrolira svoje postupke i teško podnosi školsku disciplinu. Emocionalna zrelost neposredno je vezana za socijalnu zrelost jer dijete koje slabo kontrolira svoje postupke i emocije ostala će djeca izbjegavati ili mu se rugati. Socijalno zrelo dijete usvojilo je određene norme ponašanja što mu dozvoljava samostalno zadovoljenje nekih svojih osnovnih potreba, surađivanja s djecom i odraslima i podređivanje vlastite želje pravilima i ciljevima grupe kojoj pripada (Hitrec, 1991).

\section{Upitnik za procjenu zrelosti za upis u prvi razred}

Viša savjetnica za suradnike pedagoge uz pomoć ostalih stručnih suradnika pedagoga pokrenula je postupak standardizacije postupaka za upis djece u prvi razred te je 2008. godine kreiran Upitnik za procjenu zrelosti za upis u prvi razred. Na Upitniku je moguće postići 36 bodova, a sastoji se od deset područja ispitivanja. Broj ostvarenih bodova na Upitniku može se kategorizirati na sljedeći način:

1) $29-36$ izvrstan rezultat

2) $19-28$ prosječan rezultat

3) $10-18$ slabiji rezultat

4) 0 - 9 upućuje na teškoće.

Prema Režeku (1998) sljedeći su razlozi utvrđivanja zrelosti, tj. pripremljenosti za školu:

1) Zbog upoznavanja razlika i razvojnog stupnja djece jednake kronološke dobi.

2) Zbog mogućnosti upisivanja u školu mlađe i naprednije djece, kao i kasniji upis djece koja zaostaju u intelektualnom razvoju.

3) Zbog formiranja razrednih odjela po principu heterogenosti u sposobnostima.

4) Zbog upoznavanja učitelja sa sposobnostima i predznanjem djece, što omogućuje racionalniju organizaciju početka nastave i individualizacije nastave.

5) Zbog poznavanja identifikacije drugih problema i eventualnih smetnji kod učenika na početku školovanja i mogućnosti bržeg rješavanja tih problema.

Oštarčević (2008) naglašava kako dobivene rezultate treba shvatiti kao pokazatelje stanja, a u donošenju konačne odluke neophodna je suradnja svih stručnih suradnika.

\section{Govorno-jezični razvoj i matematičko predznanje}

Bogat fond riječi važan je za učenje čitanja, a čitanje priča presudno je za razvoj govora. Djeca koja još od predškolske dobi s lakoćom čitaju najčešće su ona s kojima se mnogo razgovara, odgovara na njihova pitanja, igra, šeće, posjećuju sajmovi, izložbe, kazališta, ide na izlete, putovanja, kojima se posvećuje pažnja (Peteh, 2003). Peteh (2003) navodi da značajan broj djece ima poteškoća upravo s početnim čitanjem i pisanjem i da su to manje-više djeca koje roditelji nisu pripremali i poticali ili nisu pohađala vrtiće ili „malu školu“. U Upitniku za procjenu zrelosti za upis u prvi razred govorno-jezični razvoj donosi najveći broj bodova (10), a boduju se sljedeće sastavnice: prepoznavanje slova, analiza, sinteza, čitanje i govor. Naravno, slova, pisanje i čitanje uče se u prvom razredu i nije potrebno da djeca to sve znaju već prije polaska u školu. Međutim, važna je pripremljenost djece za stjecanje vještina čitanja i pisanja, a pripremiti ih mogu roditelji, odgojitelji ili ostale djetetu bliske osobe osluškivanjem njihovih potreba i provođenjem kvalitetno osmišljenog slobodnog vremena s njima. 
Matematičko znanje sadrži tri vrste znanja: činjenično znanje (matematičke istine), konceptualno (povezanost) i proceduralno znanje (kako se što radi) pa je nužno da dijete stekne sve tri vrste znanja i da ih međusobno povezuje (Čudina-Obradović, 1999a). Kad dijete bez diranja, gledanja i odbrojavanja zna da je četiri veće od tri, onda je razumjelo bitno svojstvo broja, a to je relacija (Čudina-Obradović, 1999a). Predmatematička priprema važna je za matematičku uspješnost na kraju prvoga razreda ako djeluje na razvijanje misaonih operacija, razvijanje strategija autoregulacije, razvijanje fonološke osjetljivosti (Čudina-Obradović, 1999a). Isto kao čitanje i pisanje, i brojevi se uče u prvom razredu. No, u Upitniku se pod područjem matematičkog predznanja, osim brojenja od 1 do 10 i čitanja brojeva do 10, ispituje i pridruživanje broja količini elemenata danog i određivanje odnosa među predmetima (veće, manje, jednako). Oštarčević (2008) u Priručniku navodi kako bi šestogodišnjaci i sedmogodišnjaci trebalirazlikovati parametre različitih veličina nekog predmeta, imati pojam količine i biti u stanju grupirati predmete. Matematičko predznanje donosi osam bodova pa je time također bitna sastavnica Upitnika.

\section{Polazak djeteta u školu}

Polazak u školu djeca različito doživljaju, no promjene ne osjećaju samo oni, nego i svi drugi uključeni subjekti od kojih su svakako najvažniji roditelji odnosno obitelj. Jedan od načina na koji bi se uloge lakše usvajale je usuglašenost očekivanja od dječjeg vrtića, osnovne škole, obitelji, djeteta i šire okoline. Usuglašavanje očekivanja odnosi se na zajedničko dijeljenje osnovnih ciljeva, svrhe, vrijednosti i načela integriranih u proces prijelaza (Somolanji Tokić, 2016). Kao bitna predispozicija prihvaćanja nove uloge svakako je socijalna kompetencija koja se prepoznaje u djetetovoj sposobnosti reguliranja emocija, toleranciji na frustraciju, sposobnosti praćenja pravila i uputa te razvoju autonomije (Mešić, 2013). Bitno je napomenuti da spremnost djeteta ne uključuje poznavanje gradiva koje će se obrađivati tijekom prvog razreda i budućeg školovanja, već razvoj operacija mišljenja, zaključivanja, bogat fond riječi, a to se postiže provođenjem kvalitetnog vremena s djetetom (primjerice, razgovarajući, čitajući, igrajući se s njime).

\section{Metoda}

\section{Cilj istraživanja}

Cilj istraživanja bio je utvrditi povezanost rezultata Upitnika za procjenu zrelosti za upisu prvi razred osnovne škole sa školskim uspjehom na kraju prvog razreda, posebice matematičkog predznanja s uspjehom iz Matematike i govorno-jezičnog razvoja s uspjehom iz Hrvatskog jezika te ukupne bodove Upitnika s općim školskim uspjehom na kraju prvog razreda.

\section{Hipoteze istraživanja}

1) Učenici koji su na Upitniku za procjenu zrelosti za upis u prvi razred postigli između $80 \%$ $(28,8)$ i $100 \%(36)$ bodova imaju bolju prosječnu ocjenu na kraju prvog razreda nego učenici koji su postigli manje od 80 \% bodova na Upitniku za procjenu zrelosti za upis $u$ prvi razred.

2) Učenici koji su na Upitniku za procjenu zrelosti za upis u prvi razred postigli između $80 \%$ (8) i $100 \%$ (10) bodova iz govorno-jezičnog razvoja imaju bolju zaključnu ocjenu iz Hrvatskog jezika nego učenici koji su postigli manje od 80 \% bodova iz govorno-jezičnog razvoja. 
3) Učenici koji su na Upitniku za procjenu zrelosti za upis u prvi razred postigli između $80 \%$ $(6,4)$ i $100 \%(10)$ bodova iz matematičkog predznanja imaju bolju zaključnu ocjenu iz Matematike nego učenici koji su postigli manje od 80 \% bodova iz matematičkog predznanja.

\section{Ispitanici}

Istraživanje se provelo tijekom prvog polugodišta 2017./2018. školske godine u jednoj slavonskoj osnovnoj školi na namjernom uzorku od 60 učenika koji su 2016./2017. školske godine završili prvi razred, a s kojima je 2015./2016. školske godine obavljena procjena zrelosti za upis u prvi razred.

\section{Način provođenja istraživanja i postupak prikupljanja podataka}

Podaci su se prikupili uvidom u pedagošku dokumentaciju odnosno uvidom u Upitnike za procjenu zrelosti za upis u prvi razred koji su provedeni 2015./2016. školske godine te uvidom u razrednu knjigu odnosno imenik učenika prvih razreda 2016./2017. školske godine. Iz Upitnika su se ispisali ukupni bodovi koje su djeca postigla te posebno ostvareni bodovi iz govorno-jezičnog razvoja i matematičkog predznanja. Iz imenika učenika ispisale su se zaključne ocjene iz svakog predmeta te se izračunala prosječna zaključna ocjena. Osim toga, posebno se izračunala prosječna zaključna ocjena iz Hrvatskog jezika i Matematike kako bi se što detaljnije mogla provesti analiza podataka.

\section{Obrada podataka}

Podaci koji su se prikupili u osnovnoj školi obradili su se kvantitativnom analizom odnosno primjenom postupaka statističke analize. Podaci su analizirani uporabom programskih paketa SPSS 23.0 i MS Office Excela. Korištene su metode univarijatne (deskriptivna statistika) i bivarijatne (t-test, korelacija) statističke analize. U statističkoj analizi koristile su se metode usporedbe dviju varijabli. Usporedbe su provedene t-test procedurom kojom se testiralo postoji li statistički značajna razlika između promatranih varijabli (t-test). S obzirom da je broj ispitanika veći od $30(\mathrm{~N}>30)$ koristio se izračun Pearsonova koeficijenta korelacije $(r)$. Korelacija je korištena kako bi se pronašla povezanost ispitivanih varijabli, a tablični prikaz korelacijske analize sastoji se od razine značajnosti ( $p$-vrijednost) te koeficijenta Pearsonove korelacije koji govori o smjeru i intenzitetu povezanosti.

\section{ReZULTATI}

Ispitanici su učenici koji su tijekom školske godine 2016./2017. pohađali prvi razred osnovne škole u kojoj se provodilo istraživanje. Od ukupno 60 učenika njih 48,3\% bili su dječaci, dok 51,7\% uzorka čine djevojčice.

\section{Prva hipoteza}

Prema prvoj hipotezi istraživanja, učenici koji su na Upitniku za procjenu zrelosti za upis u prvi razred postigli između $80 \%(28,8)$ i $100 \%$ (36) bodova, imaju bolju prosječnu ocjenu na kraju prvog razreda nego učenici koji su postigli manje od $80 \%$ bodova na Upitniku za procjenu zrelosti za upis u prvi razred. Učenici koji su ostvarili više od 80 \% na Upitniku, što je između 29 i 36 bodova, pripadaju i kategoriji izvrsnog rezultata Upitnika.

Grafikon 1. prikazuje broj djece prema postignutim bodovima na Upitniku. Broj djece koja su postigla izvrstan rezultat, odnosno više od $80 \%$ bodova, je 27 ( $N=27,45 \%$ ). Zbrojivši 
rezultate ispod $80 \%$, ukupan broj djece koja su ostvarila prosječan i slabiji rezultat te rezultat koji utječe na teškoće je $33(\mathrm{~N}=33)$, što je prikazano i u Tablici 1.

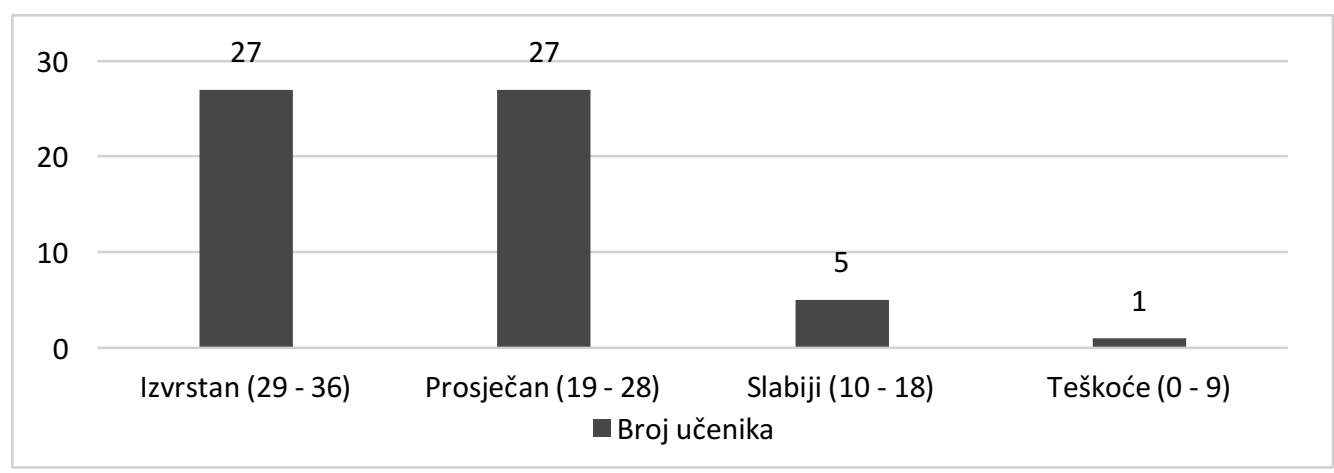

Grafikon 1. Bodovi djece postignuti na Upitniku

Na razini značajnosti od $5 \%$ ne odbacuje se prva postavljena hipoteza koja kaže da učenici koji su na Upitniku za procjenu zrelosti za upis u prvi razred postigli između $80 \%(28,8)$ i $100 \%$ (36) bodova imaju bolju prosječnu ocjenu na kraju prvog razreda nego učenici koji su postigli manje od $80 \%$ bodova na Upitniku ( $\mathrm{t}=9,313$, df $=48,376, \mathrm{p}=0,000)$. Razlika u prosječnom broju ostvarenih bodova onih koji imaju manje od $80 \%(\bar{x}=22,67)$ i onih koji imaju više od $80 \%(\bar{x}=32,19)$ statistički je značajna (Tablica 1.).

Tablica 1. Ukupan rezultat upitnika prema \% uspješnosti

\begin{tabular}{|c|c|c|c|c|}
\hline Ukupan rezultat upitnika (36) 2015./2016. & $\mathrm{N}$ & $\bar{x}$ & std. dev. & $\mathrm{t}$-test \\
\hline$<=80 \%$ & 33 & 22,67 & 5,164 & $\begin{array}{c}\mathrm{t}=9,313 \\
\mathrm{p}=0,000\end{array}$ \\
\cline { 1 - 4 } & 27 & 32,19 & 2,527 & $\mathrm{df}=48,376$ \\
\hline
\end{tabular}

Tablica 2. predstavlja korelacijsku analizu varijable Ukupan rezultat Upitnika i Prosječne zaključne ocjene 2016./2017. Nakon provedene analize zaključuje se da su navedene varijable umjereno pozitivno korelirane te je ta korelacija statistički značajna $(p<0,01)$.

Tablica 2. Korelacijska analiza Ukupnog rezultata Upitnika

\begin{tabular}{|l|c|c|}
\hline \multicolumn{2}{|c|}{} & Ukupan rezultat Upitnika (36) 2015./2016. \\
\hline $\begin{array}{l}\text { Prosječna zaključna ocjena } \\
\text { 2016./2017. }\end{array}$ & Pearsonov koef. kor. & $.687^{* *}$ \\
\cline { 2 - 3 } & p-vrijednost & .000 \\
\hline
\end{tabular}

${ }^{* *} p<0,01$

Pearsonov koeficijent korelacije je 0,687 što pripada umjerenoj korelaciji odnosno ukupan rezultat Upitnika bitno je povezan s boljom prosječnom ocjenom na kraju prvog razreda. 


\section{Druga hipoteza}

Druga hipoteza odnosi se na povezanost postignutih bodova iz govorno-jezičnog razvoja Upitnika i zaključne ocjene iz Hrvatskoga jezika na kraju prvog razreda. U Tablici 3. prikazan je broj djece koja su postigla više od $80 \%$ na Upitniku iz govorno-jezičnog razvoja $(\mathrm{N}=28)$ i onih koji su postigli $80 \%$ ili manje $(N=32)$. Prikazana je i aritmetička sredina $(x)$, standardna devijacija te je napravljena provjera nul-hipoteze (t-test).

Tablica 3. Ukupan rezultat Upitnika - govorno-jezični razvoj prema \% uspješnosti

\begin{tabular}{|c|c|c|c|c|}
\hline Upitnik - govorno-jezični razvoj 2015./2016. & $\mathrm{N}$ & $\bar{x}$ & std. dev. & t-test \\
\hline$<=80 \%$ & 32 & 4,16 & 0,954 & \multirow{2}{*}{$\begin{array}{r}t=4,118 \\
p=0,000 \\
d f=38,517\end{array}$} \\
\hline $81 \%+$ & 28 & 4,89 & 0,315 & \\
\hline
\end{tabular}

Na razini značajnosti od $5 \%$ ne odbacuje se druga postavljena hipoteza koja kaže kako učenici koji su na Upitniku za procjenu zrelosti za upis u prvi razred postigli između $80 \%$ (8) i $100 \%$ (10) bodova iz govorno-jezičnog razvoja imaju bolju zaključnu ocjenu iz Hrvatskog jezika nego učenici koji su postigli manje od $80 \%$ bodova iz govorno-jezičnog razvoja $(t=2,637, \mathrm{df}=$ $15,168, p=0,019)$. Razlika u prosječnom broju ostvarenih bodova onih koji imaju manje od 80 $\%(\bar{x}=4,16)$ i onih koji imaju više od $81 \%(\bar{x}=4,89)$ statistički je značajna (Tablica 3.).

Tablica 4. Korelacijska analiza Upitnika govorno-jezičnog razvoja

\begin{tabular}{|l|c|c|}
\hline \multicolumn{2}{|c|}{} & $\begin{array}{c}\text { Upitnik govorno-jezični } \\
\text { razvoj 2015./2016. }\end{array}$ \\
\hline \multirow{2}{*}{ Zaključna ocjena iz Hrvatskog jezika 2016./2017. } & Pearsonov koef. kor. & $.627^{* *}$ \\
\cline { 2 - 3 } & p-vrijednost & .000 \\
\hline $\begin{array}{l}\text { Zaključna ocjena iz Hrvatskog jezika prosjek } \\
\text { 2016./2017. }\end{array}$ & Pearsonov koef. kor. & $.631^{* *}$ \\
\cline { 2 - 3 } & p-vrijednost & .000 \\
\hline
\end{tabular}

${ }^{* *} p<0,01$

U Tablici 4. prikazan je Pearsonov koeficijent korelacije varijable Upitnik govorno-jezični razvoj, varijable Zaključna ocjena iz Hrvatskoga jezika 2016./2017. ( $r=0,627)$ i Zaključna ocjena iz Hrvatskoga jezika prosjek 2016./2017 ( $r=0,631)$. Nakon provedene analize, zaključuje se da su navedene varijable umjereno pozitivno korelirane s Upitnikom govorno-jezični razvoj 2015./2016., tj. bodovi ostvareni na području govorno-jezičnog razvoja Upitnika bitno su povezani sa zaključnom ocjenom iz Hrvatskoga jezika na kraju prvog razreda. Korelacija je statistički značajna $(p<0,01)$.

\section{Treća hipoteza}

Prema trećoj hipotezi, učenici koji su na Upitniku za procjenu zrelosti za upis u prvi razred postigli između $80 \%(6,4)$ i $100 \%(10)$ bodova iz matematičkog predznanja imaju bolju zaključnu ocjenu iz Matematike nego učenici koji su postigli manje od 80 \% bodova iz matematičkog predznanja. 
TEORIJSKI I PRAKTIČNI PROBLEMI I RASPRAVE

Tablica 5. Ukupan rezultat Upitnika matematičko predznanje prema \% uspješnosti

\begin{tabular}{|c|c|c|c|c|}
\hline Upitnik matematičko predznanje 2015./2016. & $\mathrm{N}$ & $\bar{x}$ & std. dev. & t-test \\
\cline { 1 - 4 }$<=80 \%$ & 13 & 3,77 & 1,092 & $\begin{array}{c}\mathrm{t}=2,637 \\
\mathrm{p}=0,019\end{array}$ \\
\cline { 1 - 4 } $\mathrm{df}=15,168$ \\
\hline
\end{tabular}

Tablica 5. prikazuje broj učenika koji su ostvarili manje od $80 \%(N=13)$ te one koji su ostvarili više od $80 \%(\mathrm{~N}=47)$ na području matematičkog predznanja na Upitniku. Razlika u prosječnom broju ostvarenih bodova onih koji imaju manje od $80 \%(\bar{x}=3,77)$ i onih koji imaju više od $80 \%(\bar{x}=4,62)$ statistički je značajna. Na razini značajnosti od $5 \%$ ne odbacuje se treća postavljena hipoteza koja kaže da učenici koji su na Upitniku za procjenu zrelosti za upis u prvi razred postigli između $80 \%(6,4)$ i $100 \%$ (10) bodova iz matematičkog predznanja imaju bolju zaključnu ocjenu iz Matematike nego učenici koji su postigli manje od $80 \%$ bodova iz matematičkog predznanja $(t=2,637, d f=15,168, p=0,019)$.

Tablica 6. Korelacijska analiza Upitnika matematičko predznanje

\begin{tabular}{|l|c|c|}
\hline \multicolumn{2}{|l|}{} & $\begin{array}{c}\text { Upitnik matematičko } \\
\text { predznanje 2015./2016. }\end{array}$ \\
\hline \multirow{2}{*}{ Zaključna ocjena iz Matematike 2016./2017. } & Pearsonov koef. kor. & $.578^{* *}$ \\
\cline { 2 - 3 } & p-vrijednost & .000 \\
\hline \multirow{2}{*}{ Zaključna ocjena iz Matematike prosjek 2016./2017. } & Pearsonov koef. kor. & $.510^{* *}$ \\
\cline { 2 - 3 } & p-vrijednost & .000 \\
\hline
\end{tabular}

${ }^{* *} p<0,01$

Tablica 6. predstavlja korelacijsku analizu varijable Upitnik matematičko predznanje 2015./2016. te varijabli Zaključna ocjena iz Matematike 2016./2017. ( $r=0,578)$ i Zaključna ocjena iz Matematike prosjek 2016./2017. ( $r=0,510)$. Nakon provedene analize zaključuje se da su navedene varijable umjereno pozitivno korelirane s Upitnikom matematičko predznanje 2015./2016. odnosno bodovi ostvareni na području matematičkog predznanja Upitnika bitno su povezani sa zaključnom ocjenom iz Matematike na kraju prvog razreda. Korelacija je statistički značajna $(p<0,01)$.

Rezultati ovog istraživanja pokazuju da, iako je veći broj djece postigao bolje rezultate na Upitniku iz matematičkog predznanja $(N=47)$ nego iz govorno-jezičnog razvoja $(N=28)$, zaključne ocjene iz Hrvatskog jezika na kraju prvog razreda (prosjek $=4,5$ ) bolje su nego ocjene iz Matematike (prosjek =4,43), što prikazuje i grafikon 2.

Razlika između zaključnih ocjena navedenih dvaju predmeta i nije toliko velika. Međutim, kad se osvrne na rezultat Upitnika, može se primijetiti da je prosjek postignutih bodova u govorno-jezičnom području 6,23 (od mogućih 10), što iznosi 62,3 \%, a u matematičkom predznanju 6,73 (od mogućih 8), što je 84,125\%. Prema tome, iako su djeca postigla bolje rezultate iz matematičkog predznanja, prosjek zaključnih ocjena iz Matematike na kraju prvog razreda slabiji je nego prosjek zaključnih ocjena iz Hrvatskoga jezika. 


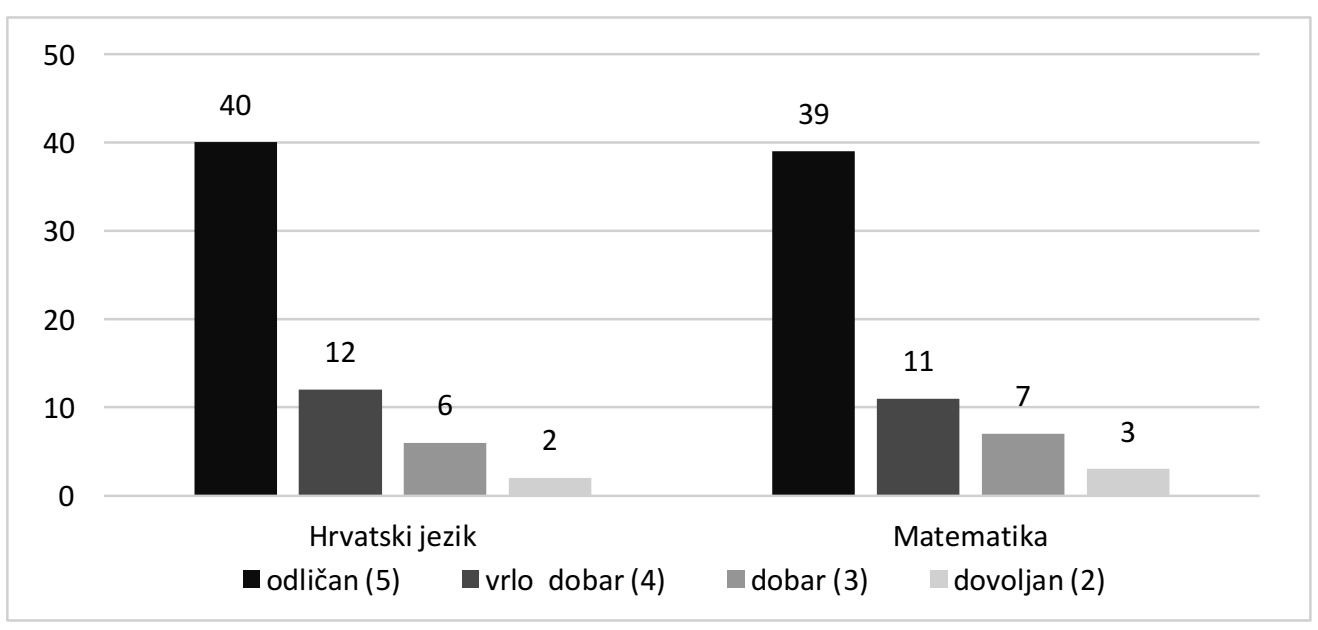

Grafikon 2. Zaključne ocjene iz Hrvatskog jezika i Matematike na kraju prvog razreda 2016./2017.

\section{RASPRAVA}

Dobiveni rezultati ukazuju na povezanost spremnosti djeteta kod provođenja ispitivanja školske pedagoginje i njihova općeg uspjeha na kraju školske godine te uspjeha u Matematici i Hrvatskom jeziku.

Što se tiče potvrđivanja prve hipoteze, do sličnih rezultata došao je i Zhang (2013) koji je istraživanje proveo u ruralnoj Kini. Rezultati njegova istraživanja također su pokazali značajnu povezanost školske spremnosti sa školskim uspjehom. Osim toga, slično istraživanje provela je i Fitzpatrick (2011) u Kanadi gdje su rezultati ukazali da dječja spremnost pri ulasku u školu prognozira kasnije akademsko postignuće te je bitna ranija uključenost djece u raznovrsne aktivnosti jer ona utječe na prilagodbu u školi i školsko postignuće. Međutim, Fitzpatrick (2011) naglašava da spremnost djece pri ulasku u školu ne utječe samo na bolje rezultate u prvom razredu ili općenito u osnovnoj školi, već i na završavanje srednjoškolskog obrazovanja koje, pak, predviđa potencijal pojedinca za cjeloživotno učenje i profesionalni uspjeh. Budući da je školska spremnost povezana sa školskim uspjehom, postavlja se pitanje kako doći do takve spremnosti, a koja će kasnije dovesti do boljeg školskog uspjeha. Tu se važnim može smatrati bavljenje roditelja ili skrbnika djetetom prije uključivanja u obrazovni sustav. Obitelj je prva institucija u koju dijete ulazi i u kojoj svladava vještine, sposobnosti i znanja korisne za budućnost i uključivanje u druge institucije.

Druga hipoteza pokazuje da su bodovi ostvareni na području govorno-jezičnog razvoja Upitnika bitno povezani sa zaključnom ocjenom iz Hrvatskog jezika na kraju prvog razreda. No, tu je važno naglasiti da je nepotrebno pretjerano naglašavanje akademskih vještina kod predškolaraca te da je za njihov cjeloviti razvoj važnija igra, što upućuje na to da djeca prije polaska u školu ne trebaju znati čitati. Mnogi autori (Hitrec, 1991; Peteh, 2003; Mešić, 2013) to potvrđuju te navode kako je bitnije čitanje priča djeci, razgovaranje s njima i odgovaranje na njihova pitanja jer se time proširuje djetetov rječnik, a što je korisno za precizno izražavanje. Priprema za učenje čitanja podrazumijeva poticanje djeteta za samostalno govorenje, dok se analiza $\mathrm{i}$ sinteza riječi može razviti igranjem raznovrsnih jezičnih igara. Istraživanje Marjanovič Umek i sur. (2006) u Sloveniji pokazalo je da govorne kompetencije naznačuju visoku spremnost za školu. Također, Sindik (2004) navodi kako je najbolja skupina pokazatelja opće pripremljenosti za školu varijabla govornih sposobnosti. Hitrec (1991) naglašava da mnogi roditelji griješe u 
tome što prije početka školovanja forsirano uče dijete čitati i pisati u želji da mu olakšaju rad u nastavi, a prema iskustvu svakog učitelja neusporedivo je bolja priprema za školu ona koja se odvija igrama i različitim aktivnostima. Roditelji trebaju ponuditi materijal i interes za ono što dijete radi isto kao što se to nudi u vrtićima i predškolskim ustanovama. Prema Nacionalnom kurikulumu za rani i predškolski odgoj i obrazovanje (2014) djetetu je važno osigurati radost otkrivanja i učenja igrom i drugimdjetetu zanimljivim aktivnostima. Nepoznavanjem slova i čitanja možda se neće ostvariti maksimalan broj bodova u području govorno-jezičnog razvoju na Upitniku, no ako se djetetu čita i razgovara s njime, potiče ga se na jezične igre i provodi vrijeme s njime, ono će usvojiti kvalitetnu podlogu za nadograđivanje znanja. Osim toga, na Upitniku se boduje i sam govor što znači da roditelji i ostali subjekti uključeni u odgoj djetetu trebaju biti uzor pri izgovaranju riječi i rečenica jer dijete uči po modelu oponašanjem. Ukoliko izostane opisan pristup predškolskom djetetu, tada će ono teže usvojiti slova, svladati tehniku čitanja te razumjeti analizu i sintezu, a to će utjecati na slabiju prosječnu zaključnu ocjenu iz Hrvatskog jezika na kraju prvog razreda, što su i pokazali rezultati ovog istraživanja.

Od analiziranih triju hipoteza matematičko predznanje najmanje je povezano s rezultatima na kraju prvog razreda, a može se objasniti time što na uspjeh u Matematici utječe i razvijanje fonološke osjetljivosti. Osim toga, u Upitniku iz matematičkog predznanja ne provjeravaju se konkretni pojmovi koji će se učiti u prvom razredu, primjerice kao što se u govornojezičnom razvoju boduje prepoznavanje slova i čitanje, a što je zapravo gradivo Hrvatskog jezika tijekom cijelog prvog razreda. U Nastavnom planu i programu za osnovnu školu (2006, str. 25) stoji: „Početno čitanje i pisanje osobitost je prvog razreda i provodi se cijele školske godine." $\mathrm{S}$ druge strane, iako se i u Matematici uče pojmovi koje se provjeravaju u Upitniku (brojevi do 10, odnosi među predmetima), u programu iz Matematike navedeno je i usvajanje uspoređivanja brojeva do 20 te zbrajanje i oduzimanje brojeva do 20 , što je ipak kompleksnije gradivo. ČudinaObradović (1999a) navodi važnost predmatematičke pripreme za matematičku uspješnost na kraju prvog razreda ukoliko djeluje na razvijanje misaonih operacija i razvijanje strategija autoregulacija (usmjerenje pozornosti, prepoznavanje vremenskoga i prostornog slijeda, anticipaciju i generalizaciju). Rezultati njezina istraživanja pokazuju da je matematička pripremljenost značajan čimbenik buduće matematičke uspješnosti, ali samo uz uvjet djetetove razvijene fonološke osjetljivosti i primjene korespondencije glas - slovo. Roditelji trebaju uvoditi djecu u razumijevanje odnosa među predmetima (Mešić, 2013). Tiedemannovo (1987, prema ČudinaObradović, 1999a) longitudinalno praćenje prvoškolaca nije pokazalo povezanost predškolskog matematičkog znanja s uspjehom u Matematici na kraju prvog razreda ako se uzme u obzir djetetova inteligencija. Djeca koja prije polaska u školu imaju razvijene operacije mišljenja lako će i brzo usvojiti matematička predznanja, dok matematička predznanja koja nisu temeljena na pravom razumijevanju uz razvijene misaone operacije neće dovesti do pravog znanja matematike. Duncan i sur. (2006) u istraživanju su došli do rezultata kako je od predmatematičkih vještina najvažniji pokazatelj budućeg uspjeha bilo poznavanje brojeva i osjećaj za redoslijed veličina. S druge strane, Le i sur. (2006) u svom longitudinalnom istraživanju ističu važnost razvijenosti fine motorike i pozitivnih stavova prema učenju za uspjeh u matematici.

Dobivenim rezultatima može se pretpostaviti kako su zadaci iz matematičkog predznanja djeci lakši nego što će im biti predmet Matematika u prvom razredu. S Hrvatskim jezikom je obrnuto - djeca su na govorno-jezičnom razvoju postigla slabiji rezultat dok im je predmet Hrvatski jezik lakši kad ga počnu kontinuirano učiti. Do sličnih rezultata došli su i Duncan i sur. (2006) koji su u provedenom istraživanju zaključili kako matematičko predznanje utječe na kasnije postignuće čitanja dok čitanje toliko ne utječe na kasnije razvijanje matematičkih vještina. 


\section{ZAKUUČAK}

Svrha istraživanja i njegove teorijske pozadine jest dobivanje uvida u psihofizičku zrelost djeteta prije polaska u školu, vrijednosti i obilježja ispitivanja psihofizičkog stanja djeteta te ispitivanje povezanosti rezultata Upitnika za procjenu zrelosti za upis u prvi razred sa školskim uspjehom na kraju prvog razreda osnovne škole. Teorijska podloga istraživanja ukazala je da postoji mnogo međusobno povezanih faktora koji utječu na uspješnu pripremu djeteta za školu: psihofizička zrelost - fizička, intelektualna, socijalna i emocionalna; motivacija i poticaji djeteta od strane roditelja/skrbnika i svih ostalih subjekata uključenih u djetetov život; djetetova znatiželja, samokontrola, pozitivni stavovi prema učenju i školi.

Istraživanje je dalo očekivane rezultate odnosno sve su tri postavljene hipoteze potvrđene. Rezultati istraživanja ukazali su na povezanost spremnosti djeteta kod provođenja ispitivanja školske pedagoginje i njihova uspjeha na kraju školske godine.

Razlozi ispitivanja spremnosti za školu uključuju upoznavanje učitelja i stručne službe s razvojnim razlikama među učenicima te sposobnostima i predznanjem djece kako bi se omogućio individualizirani pristup nastavi i učenicima, ali i kako bi se učenici mogli ravnomjerno podijeliti u razredne odjele prema svim dobivenim pokazateljima (spol, rezultati ispitivanja, preporuke liječnika medicine, adresa stanovanja). Provođenje ispitivanja školskog pedagoga i ostalih članova Stručnog povjerenstvaomogućuje prikladnu i pravovremenu organizaciju rada s učenicima koji su postigli slabije rezultate na ispitivanju kako bi tijekom školske godine, ali i kasnije, uspjeli svladati i usvojiti ona znanja, vještine i sposobnosti u kojima su pokazali slabiju pripremljenost. Također, rezultati ispitivanja omogućuju i prikladnu organizaciju rada s učenicima koji su postigli visoke rezultate kako bi se i dalje njihovi misaoni procesi razvijali u pravom smjeru. Prikladan rad s učenicima postignutih slabijih rezultata može uključivati organiziranje dopunske nastave i/ili produženog boravka gdje bi se takvim učenicima moglo posvetiti više pozornosti. Osim toga, te učenike stručni suradnici mogu uključiti u različite radionice i aktivnosti koje bi poticale učeničku motivaciju i znatiželju, stvaralačko mišljenje, kreativnost u rješavanju problema. Može se zaključiti da je bitna pravovremena reakcija i djelovanje svih subjekata uključenih u život djeteta kako bi mu se omogućio pravilan razvoj i primjereno stjecanje znanja, vještina i sposobnosti potrebnih za nastavak obrazovanja.

U sljedećim istraživanjima bilo bi vrijedno istražiti što je sve utjecalo na pripremu uključene djece $u$ istraživanje za polazak u školu. Nadalje, ovo istraživanje ispitalo je uspjeh učenika na kraju prvog razreda, a mogla bi se istražiti i povezanost rezultata Upitnika s uspjehom na kraju četvrtog i/ili osmog razreda te na kraju srednjoškolskog obrazovanja.

\section{LITERATURA}

Čudina-Obradović, M. (1999a). Oblici matematičke pripremljenosti za školu i njena važnost za uspjeh u učenju matematike: prijedlog suvremenog modela. Bjelovarski učitelj, 8(2-3), 52-60.

Čudina-Obradović, M. (1999b). Odrednice i posljedice matematičke pripremljenosti za školu. Napredak, 140(3), 330-340.

Duncan, G. J. i sur. (2006). School Readiness and Later Achievement. Developmental Psychology, 43(6), 1428-1446.

Fitzpatrick, C. (2011). Kindergarten Classroom Engagement Skills: The Road to Academic Success in Elementary School. Montreal: The University of Montreal.

Furlan, I. (1984). Čovjekov psihički razvoj. Zagreb: Školska knjiga.

Hadžiselimović, Dž. i Vukmirović, ž. (1999) Priručnik - test spremnosti za školu (TSŠ). Rijeka: Filozofski fakultet u Rijeci, Odsjek za psihologiju. 
Hitrec, G. (1991). Kako pripremiti dijete za školu. Zagreb: Školska knjiga.

Le, V. N., Kirby, S. W., Barney, H., Setodji, C.M. i Gershwin, D. (2006). School readiness, full-day kindergarten and student achievement. Preuzeto s https://www.rand.org/content/dam/rand/ pubs/monographs/2006/RAND_MG558.pdf, 9.1.2018.

Lemelin, J. P., Boivin, M., Forget-Dubois, N., Dionne, G., Seguin, J.R. i sur. (2007). The genetic-environmental etiology of cognitive school readiness and later academic achievement, Child Development, 78, 1856-1862.

Mahmatović, A. (2013). Značaj igre u socijalizaciji djece predškolskog uzrasta. Metodički obzori, 8(2), 21-33.

Marjanovič Umek, Lj., Kranjc, S., Fekonja, U. i Bajc (2006). Dejavniki otrokove pripravnosti za šolo. Društvo psihologov Slovenije 2006, 15(2), 31-51.

Markulin, D. i Simić, Z. (2003). Razvoj kognitivnih sposobnosti djece u godini pred polazak u školu U: Bacalja, R. (ur.), Djetinjstvo, razvoj i odgoj: zbornik radova sa znanstveno-stručnog skupa (str. 231-235). Zadar: Sveučilište u Zadru - Stručni odjel za izobrazbu učitelja i odgojitelja predškolske djece.

Mešić, A. (2013). Smjernice za pripremu i polazak djece u školu. Školski vjesnik: časopis za pedagogijsku teoriju i praksu, 62(1), 121-130.

Narodne novine (2008). Zakon o odgoju i obrazovanju u osnovnoj i srednjoj školi. Preuzeto s https://narodne-novine.nn.hr/clanci/sluzbeni/2008_07_87_2789.html, 15.2.2018.

Narodne novine (2014). Pravilnik o postupku utvrđivanja psihofizičkog stanja djeteta, učenika te sastavu stručnih povjerenstava. Preuzeto s https://narodne novine.nn.hr/clanci/sluzbeni/2014_ 06_67_1279.html, 16.2.2018.

Oštarčević, J. (2008). Priručnik za upis djece u prvirazred. Zagreb: Agencija za odgoj i obrazovanje.

Ministarstvo znanosti, obrazovanja i sporta (2014). Nacionalni kurikulum za rani i predškolski odgoj. Zagreb.

Peteh, M. (2003). Svako slovo nešto novo. Zagreb: Alinea.

Režek, S. (1998). Procjena psihofizičke zrelosti djece dorasle za upis u osnovnu školu. Medix, $4(21 / 22), 142-145$.

Sindik, J. (2004). Ispitivanje zrelosti djece za školu - primjena dvaju upitnika. U: Babić, N., Irović, S. i Redžeš-Borak, Z. (ur.), Zbornik radova stručnog i znanstvenog skupa: Rastimo zajedno (319-324). Osijek: Visoka učiteljska škola Osijek ; Centar za predškolski odgoj Osijek : Grafika.

Somolanji Tokić, I. i Kretić Majer, J. (2015). Dijete kao aktivni sudionik polaska u osnovnu školu. Život i škola, 61(1), 103-110.

Somolanji Tokić, I. (2016). Kompetencije učitelja i polazak djeteta u osnovnu školu u svjetlu nove kurikularne reforme. Školski vjesnik, 65(3), 423-440.

Starc, B., Čudina-Obradović, M., Pleša, A., Profaca, B. i Letica, M. (2004). Osobine i psihološki uvjeti razvoja djeteta predškolske dobi: priručnik za odgojitelje, roditelje i sve koji odgajaju djecu predškolske dobi. Zagreb: Tehnička knjiga.

Vican, D. i Milanović Litre, I. (ur.) (2006). Nastavni plan i program za osnovnu školu. Zagreb: Ministarstvo znanosti, obrazovanja i športa.

Zhang, L. (2013). Preschool Experience, School Readiness, Self-regulation, and Academic Achievement: A Longitudinal Study in Rural China. Hong Kong: The University of Hong Kong, Pokfulam. 
Lana Jelinek

POVEZANOST ZRELOSTI UČENIKA NA UPISU U PRVI RAZRED I.

\title{
The Connection between the Maturity of the Student while Enrolling First Grade and Their Success at the End of the School year
}

\begin{abstract}
The paper explains the results of the examination of school children, which are carried out by the school counselor, in relation to their success at the end of the first grade. It studies their maturity and readiness to start going to the first class. The goal of this research is to determine if the results of The questionnaire for first grade maturity assessment are connected with school success, especially regarding the connection of prior mathematical knowledge with later mathematical success and the connection of verbal language development with success in Croatian language, as well as total points od the questionnaire with grade results report at the end of the first grade. The research is conducted on the sample of 60 students who finished first grade in 2015/2016 school year, and who passed The questionnaire for first grade maturity assesment in 2015/2016 school year. The data was collected through pedagogical documentation analysis, i.e. through examination of the first grade book (school register) and through The questionnaire for first grade maturity assessment. The results claim that there is a correlation between the child's readiness during the school counselor's assessment protocol and their success at the end of the school year. The results of The questionnaire are important for the school counselor in order to be able to divide the students into classes evenly and to inform the teachers and their advisory services of the development differences between students, their abilities and prior knowledge.
\end{abstract}

Keywords: verbal language development, prior mathematical knowledge, first grade, school success, school maturity

\section{Zusammenhang zwischen der Reife der Schüler bei der Einschreibung in die erste Klasse und ihrem Erfolg am Schuljahresende}

Zusammenfassung: Die Arbeit befasst sich mit den Befragungsergebnissen bei schulpflichtigen Kindern, die der Schulpädagoge durchführt, und ihrem Erfolg am Ende der ersten Klasse. Es wurde geprüft, was man unter der Reife und Bereitschaft des Kindes für den Start in die erste Klasse betrachtet. Das Ziel war es festzustellen, ob die Ergebnisse des Fragebogens für die Schulreife-Einschätzung der ersten Klasse mit dem Schulerfolg zusammenhängen, insbesondere mathematische Vorkenntnisse mit dem Erfolg in Mathematik und Sprachentwicklung mit dem Erfolg in der kroatischen Sprache sowie die Gesamtpunkte des Fragebogens mit Allgemeinschulerfolg am Ende der ersten Klasse. Die Prüfung wurde an einer Stichprobe von 60 Schülern durchgeführt, die 2016/2017 die erste Klasse beendeten und mit denen 2015/2016 die Schulreife-Einschätzung für die Einschreibung in die erste Klasse erledigt wurde. Die Angaben wurden durch Analyse der pädagogischen Dokumentation, beziehungsweise durch die Klassenbucheinsicht der Schüler erster Klasse und durch die Einsicht des Fragebogens zur Reifeeinschätzung für die Einschreibung in die erste Klasse erhoben. Die erzielten Ergebnisse deuten auf den Zusammenhang zwischen der Bereitschaft der Kinder bei der Prüfungsdurchführung der Schulpädagogin und ihrer Erfolge am Schuljahresende. Die Ergebnisse des Fragebogens sind wichtig, um die Schüler gleichmäßig in Klassen einordnen zu können und damit sich die Lehrer und Fachkräfte mit den Entwicklungsunterschieden, Fähigkeiten und Vorkenntnissen der Schüler vertraut machen.

Schlüsselwörter: Sprachentwicklung, mathematische Vorkenntnisse, erste Klasse, Schulerfolg, Schulreife 